\title{
Pharmacokinetics and dose adjustment of etoposide administered in a medium-dose etoposide, cyclophosphamide and total body irradiation regimen before allogeneic hematopoietic stem cell transplantation
}

\author{
Yuki Tazawa ${ }^{1,3}$, Akio Shigematsu², Kumiko Kasashi ${ }^{3}$, Junichi Sugita², Tomoyuki Endo², Takeshi Kondo²,
} Takanori Teshima ${ }^{2}$, Ken Iseki ${ }^{3}$, Mitsuru Sugawara ${ }^{1,4}$ and Yoh Takekuma ${ }^{1 *}$

\begin{abstract}
Background: We investigated the pharmacokinetics of etoposide (ETP) to reduce the inter-individual variations of ETP concentrations in patients with acute leukemia who underwent allogeneic hematopoietic stem cell transplantation. We also carried out an in vivo study using rats to verify the dose adjustment.

Methods: This study included 20 adult patients. ETP was administered intravenously at a dose of $15 \mathrm{mg} / \mathrm{kg}$ once daily for 2 days (total dose: $30 \mathrm{mg} / \mathrm{kg}$ ) combined with standard conditioning of cyclophosphamide and total body irradiation. In an in vivo study using rats, ETP was administered intravenously at a dose of $15 \mathrm{mg} / \mathrm{kg}$ or an adjusted dose. The ETP plasma concentration was determined by using HPLC. The pharmacokinetic parameters were estimated by using a 1-compartment model.
\end{abstract}

Results: The peak concentration $\left(C_{\max }\right)$ of ETP and the area under the plasma concentration-time curve (AUC) of ETP differed greatly among patients (range of $C_{\text {max }} 51.8-116.5 \mu \mathrm{g} / \mathrm{mL}$; range of AUC, $870-2015 \mu \mathrm{g} \cdot \mathrm{h} / \mathrm{mL}$ ). A significant relationship was found between $C_{\max }$ and $\operatorname{AUC}(R=0.85, P<0.05)$. Distribution volume $(\mathrm{Vd})$ was suggested to be one of the factors of inter-individual variation in plasma concentration of ETP in patients (range of $V d, 0.13-0.27 \mathrm{~L} / \mathrm{kg}$ ), and correlated with Alb and body weight $(R=0.56, P<0.05 ; R=0.40, P<0.05$ respectively). We predicted $V d$ of rats by body weight of rats (with normal albumin levels and renal function), and the dose of ETP was adjusted using predicted $V \mathrm{~d}$. In the dose adjustment group, the target plasma ETP concentration was achieved and the variation of plasma ETP concentration was decreased.

Conclusion: The results suggested that inter-individual variation of plasma concentration of ETP could be reduced by predicting $\mathrm{Vd}$. Prediction of $\mathrm{Vd}$ is effective for reducing individual variation of ETP concentration and might enable a good therapeutic effect to be achieved.

Keywords: Medium-dose etoposide, Allogeneic hematopoietic stem cell transplantation, Pharmacokinetics, Dose adjustment, Distribution volume

\footnotetext{
* Correspondence: y-kuma@pharm.hokudai.ac.jp

${ }^{1}$ Laboratory of Pharmacokinetics, Faculty of Pharmaceutical Sciences,

Hokkaido University, Kita-12 Nishi-6, Kita-ku, Sapporo, Hokkaido 060-0812,

Japan

Full list of author information is available at the end of the article
} 


\section{Background}

Allogeneic stem cell transplantation (allo-SCT) has been used to treat patients with hematological malignancies. High-dose intravenous etoposide (ETP) is commonly used with a standard conditioning regimen of cyclophosphamide (CY) and total body irradiation (TBI) [1-6]. However, it has been reported that the pharmacokinetic parameters of ETP were highly variable between individuals [7]. There have been many studies on the pharmacokinetics (PK) of ETP but only a few studies on leukemia patients who received high-dose ETP as a conditioning regimen and underwent allo-SCT $[8,9]$. Moreover, the optimal dose of ETP has not been clarified.

In this study, we focused on PK and dose adjustment of ETP in adult patients with acute leukemia and also verified the dose adjustment in experimental rats based on the PK parameters to reduce large variations of plasma ETP concentration.

\section{Methods \\ Patients and pharmacokinetic analysis Patients}

PK of ETP was evaluated in 20 patients who underwent allo-SCT using a conditioning regimen of medium-dose ETP + CY + TBI between April 2008 and January 2013 at Hokkaido University Hospital. A summary of the characteristics of the patients is shown in Table 1 . Both the Protocol Review Committee and the Institutional Review Board of Hokkaido University Hospital approved the study. Written informed consent was obtained from all of the patients.

\section{Conditioning regimen and graft-versus-host disease (GVHD) prophylaxis}

All patients received the same conditioning regimen of medium-dose ETP $+\mathrm{CY}+\mathrm{TBI}$, which consisted of ETP at a dose of $15 \mathrm{mg} / \mathrm{kg}$ once daily administered intravenously (i.v.) over $3 \mathrm{~h}$ for 2 days (total dose: $30 \mathrm{mg} / \mathrm{kg}$ ) and $\mathrm{CY}$ at $60 \mathrm{mg} / \mathrm{kg}$ once daily administered i.v. over $3 \mathrm{~h}$ for 2 days (total dose: $120 \mathrm{mg} / \mathrm{kg}$ ) followed by 12 Gy of TBI delivered in 4 or 6 fractions for 2 or 3 days, as reported previously [10-13]. GVHD prophylaxis was provided with short-term methotrexate and cyclosporine (CSP) or tacrolimus (TAC) according to the physician's selection.

\section{Blood samples of patients}

Blood samples were drawn before the start of ETP infusion (blank plasma) and at 1, 3, 6, 10, 24, 25, 27, 30, 34, 44,68 , and $92 \mathrm{~h}$ after the first infusion. The samples were collected into tubes containing heparin. The samples were centrifuged at $750 \times \mathrm{g}$ for $10 \mathrm{~min}$ at $4{ }^{\circ} \mathrm{C}$ to obtain plasma, and the plasma was frozen at $-20^{\circ} \mathrm{C}$ until analysis. All patients gave informed consent and agreed to the multiple blood sampling procedure.

\section{Analytical procedure}

ETP plasma concentration was determined by using HPLC. Analytical ETP was purchased from LKT Laboratories Inc. (St. Paul, MN, USA). It was dissolved in dimethyl sulfoxide (DMSO) (stock concentration: $20 \mathrm{mg} / \mathrm{mL}$ ) and stored at $-20{ }^{\circ} \mathrm{C}$. Acetonitrile, dichloromethane, and methanol were of liquid chromatographic grade. Control plasma was provided by Japanese Red Cross Blood Center (Hokkaido, Japan) and stored at $-20{ }^{\circ} \mathrm{C}$. The internal standard, diphenyl hydantoin (DPH) was purchased from Wako Pure Chemical Industries, Ltd. (Osaka, Japan). ETP plasma concentration was determined by the method of kato et al. [14]. Briefly, $20 \mu \mathrm{L}$ of $\mathrm{DPH}$ at a concentration of $100 \mu \mathrm{g} / \mathrm{mL}$ (in methanol), $1 \mathrm{~mL}$ of distilled water and $200 \mu \mathrm{L}$ of plasma were added to a glass test tube with a screw cap. After $5 \mathrm{~mL}$ of dichloromethane had been added, the mixture was shaken for $15 \mathrm{~min}$ and then centrifuged at $750 \times \mathrm{g}$ for $5 \mathrm{~min}$. Four $\mathrm{mL}$ of the dichloromethane layer was evaporated to dryness at $40{ }^{\circ} \mathrm{C}$ in a vacuum evaporator. The residue was redissolved in $200 \mu \mathrm{L}$ of the mobile phase of HPLC and was subjected to HPLC. The injection volume of a sample was $40 \mu \mathrm{L}$. The HPLC system consisted of an L-7110 pump, L-7300 column oven, L-7420 UV-VIS detector, and D-2500 integrator (HITACHI, Tokyo, Japan). The column was an Inersil ODS-4 (100 $\mathrm{mm} \times 2.1 \mathrm{~mm}$ i.d., $3 \mu \mathrm{m})$ (YOKOHAMARIKA CO., Yokohama, Japan). A mobile phase containing methanol/distilled water/acetonitrile (42.7: $55: 2.3, \mathrm{v} / \mathrm{v} / \mathrm{v}$ ) was used at a flow rate of $0.4 \mathrm{~mL} / \mathrm{min}$. The detector was monitored at $229 \mathrm{~nm}$.

\section{Pharmacokinetic analysis}

The pharmacokinetic parameters were estimated by using a 1-compartment model. The peak concentration $\left(\mathrm{C}_{\max }\right)$ and the trough concentration $\left(\mathrm{C}_{\min }\right)$ of ETP in plasma were obtained directly from the analytical data. The volume of distribution (Vd) was calculated as Dose/ $\mathrm{C}_{0}\left(\mathrm{C}_{\mathrm{max}}\right)$. The elimination rate constant $\left(\mathrm{K}_{\mathrm{el}}\right)$ was calculated by log-linear regression of ETP concentration data during the elimination phase. The clearance (CL) was calculated as $\mathrm{K}_{\mathrm{el}} \times \mathrm{Vd}$. The area under the plasma concentration-time curve (AUC) was calculated by the trapezoidal rule. Mean values of $\mathrm{Vd}$ on the first day and second day were used for subsequent investigation.

\section{Experimental animals and pharmacokinetic analysis Animals and treatment}

Male Wistar rats were obtained from Hokudo Co., Ltd. (Sapporo, Japan). The experimental protocols were reviewed by the Animal Care Committee in accordance with the Guide for the Care and Use of Laboratory Animals. ETP for intravenous infusion was purchased from Sandoz (Tokyo, Japan). ETP was diluted in normal saline. ETP solution was administrated intravenously at 
Table 1 Characteristics of the patients $(n=20)$

\begin{tabular}{|c|c|c|c|c|}
\hline & & Mean \pm S.D. & Median & Range \\
\hline Age (year) & & $31.8 \pm 7.0$ & 31 & $18-44$ \\
\hline Sex (male/female) & $15 / 5$ & & & \\
\hline Body Weight (kg) & & $67.0 \pm 12.5$ & 65.0 & $45.5-91.8$ \\
\hline Body surface area $\left(\mathrm{m}^{2}\right)$ & & $1.8 \pm 0.2$ & 1.8 & $1.4-2.1$ \\
\hline Body mass index $\left(\mathrm{kg} / \mathrm{m}^{2}\right)$ & & $23.2 \pm 3.3$ & 23.1 & $15.5-28.8$ \\
\hline \multicolumn{5}{|l|}{ Diagnosis } \\
\hline ALL & 17 & & & \\
\hline AML & 2 & & & \\
\hline ANKL & 1 & & & \\
\hline \multicolumn{5}{|l|}{ Disease status at SCT } \\
\hline CR1 & 14 & & & \\
\hline CR2 & 1 & & & \\
\hline non $C R$ & 4 & & & \\
\hline relapse 1 & 1 & & & \\
\hline \multicolumn{5}{|l|}{ Donor } \\
\hline MRD & 6 & & & \\
\hline MUD & 7 & & & \\
\hline MMRD & 1 & & & \\
\hline MMUD & 6 & & & \\
\hline \multicolumn{5}{|l|}{ Stem cell source } \\
\hline Bone marrow & 15 & & & \\
\hline Peripheral blood stem cells & 3 & & & \\
\hline Umbilical cord blood & 2 & & & \\
\hline \multicolumn{5}{|l|}{ GVHD Prophylaxis } \\
\hline $\mathrm{CSP}+\mathrm{MTX}$ & 9 & & & \\
\hline $\mathrm{TAC}+\mathrm{MTX}$ & 11 & & & \\
\hline \multicolumn{5}{|l|}{ Laboratory data } \\
\hline Alb (g/dL) & & $4.0 \pm 0.4$ & 4.0 & $2.8-4.9$ \\
\hline T-pro (g/dL) & & $6.0 \pm 0.4$ & 5.8 & $5.4-7.0$ \\
\hline $\mathrm{BUN}(\mathrm{mg} / \mathrm{dL})$ & & $10.3 \pm 3.0$ & 10.5 & $5.0-15.0$ \\
\hline $\mathrm{Scr}(\mathrm{mg} / \mathrm{dL})$ & & $0.6 \pm 0.2$ & 0.6 & $0.3-1.0$ \\
\hline T-bil (mg/dL) & & $0.7 \pm 0.3$ & 0.7 & $0.4-1.7$ \\
\hline AST (IU/L) & & $35.0 \pm 31.4$ & 21.0 & $9.0-125$ \\
\hline ALT (IU/L) & & $45.6 \pm 54.6$ & 32.0 & $5.0-251$ \\
\hline
\end{tabular}

ALL indicates acute lymphoblastic leukemia, $A M L$ acute myelogenous leukemia, $A N K L$ aggressive NK cell leukemia, SCT stem cell transplantation, $C R$ complete remission, MRD HLA-matched related donor, MUD HLA-matched unrelated donor, MMRD mismatched related donor, MMUD mismatched unrelated donor, CSP cyclosporin A, MTX methotrexate, TAC tacrolimus, Alb albumin, T-pro total protein, BUN blood urea nitrogen, $S c r$ serum creatinine, $T$-bil total bilirubin, AST asparatate aminotransferase, ALT alanine aminotransferase

a dose of $15 \mathrm{mg} / \mathrm{kg}$. At each experimental time point (before the start of ETP infusion (blank plasma) and at $0.017,0.05,0.25,0.75,1.5,3$, and $6 \mathrm{~h}$ after infusion), rats were anesthetized with diethyl ether, and whole blood was collected from the jugular vein. Plasma was obtained by centrifugation at $750 \times \mathrm{g}$ for $10 \mathrm{~min}$ at $4{ }^{\circ} \mathrm{C}$. The rats were killed by exsanguination after blood collection. ETP plasma concentration was determined by
HPLC as described above. PK parameters were determined as described above.

\section{Statistical analysis}

Student's $t$-test was used to determine the significance of differences between two group means. Pearson's test was used to determine correlations. Predictability of Vd was calculated with stepwise regression analysis using $\mathrm{JMP}^{\odot}$ 


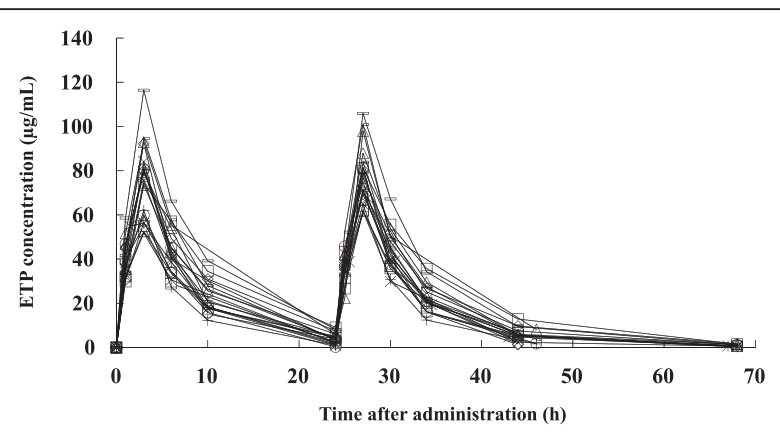

Fig. 1 Plasma concentration of ETP in patients after i.v. administration of ETP over $3 \mathrm{~h}$ at a dose of $15 \mathrm{mg} / \mathrm{kg}$ once daily for 2 days $(n=20)$

12 Pro (SAS Institute Inc., Cary, NC, USA). Statistical significance was defined as $P<0.05$.

\section{Results}

Results for the patients

Pharmacokinetic analysis of ETP in patients

The plasma concentration versus time curve and the pharmacokinetic parameters after intravenous administration of ETP are shown in Fig. 1 and Table 2, respectively. Mean $\mathrm{C}_{\max }$ on the first day was $74.9 \mu \mathrm{g} / \mathrm{mL}$ (median: 77.4 , range: 51.8 - $116.5 \mu \mathrm{g} / \mathrm{mL}$ ). Mean $\mathrm{AUC}_{0-92 \mathrm{~h}}$ was $1332 \mu \mathrm{g} \cdot \mathrm{hr} / \mathrm{mL}$ (median: 1282, range: $870-2015 \mu \mathrm{g} \cdot \mathrm{h} / \mathrm{mL}$ ). Mean values of $\mathrm{Vd}$ on the first day and second day were $0.20 \mathrm{~L} / \mathrm{kg}$ (median: 0.20 , range: $0.13-0.28$ ). A significant relationship was found between $\mathrm{C}_{\max } \quad$ (day1) and $\mathrm{AUC}_{0-92 \mathrm{~h}}(R=0.85$, $P<0.05)$. Vd was correlated with $\mathrm{Alb}$ and body weight ( $R=0.56, P<0.05 ; R=0.40, P<0.05$ respectively).

\section{Results of experiments using rats}

\section{Pharmacokinetic analysis of ETP in rats}

We investigated the pharmacokinetic parameters in rats (with normal Alb levels and renal function). The experimental rats were divided into 3 groups based on the age of rats [5 weeks (control), 7 weeks and 10 weeks] and were intravenously administered ETP at a dose of $15 \mathrm{mg} / \mathrm{kg}$. Table 3 shows the pharmacokinetic parameters of rats after infusion. $\mathrm{C}_{\max }$ and $\mathrm{AUC}$ were significantly higher in the groups of 7 weeks and 10 weeks than in the group of 5 weeks (control). $\mathrm{Vd}$ in the group of 10 weeks were lower than those in the group of 5 weeks. Kel was not significantly different among the 3 groups of rats.

\section{Dose adjustment of ETP in rats}

There was a positive correlation between body weight and $\mathrm{Vd}$ of ETP in rats (linear regression equation: $\mathrm{Vd}(\mathrm{L})=$ $0.0001 \times$ body weight $(\mathrm{g})+0.0259, \quad R=0.82, \quad P<0.05)$. Therefore, we predicted Vd from the body weights of rats and calculated the dose by the following formula: dose $(\mathrm{mg})=\mathrm{Vd}(\mathrm{L}) \times \mathrm{C}_{\max }(\mu \mathrm{g} / \mathrm{mL})$ to achieve target $\mathrm{C}_{\max }(60 \mu \mathrm{g} / \mathrm{mL})$. We set a target ETP concentration to $60 \mu \mathrm{g} / \mathrm{mL}$ because the mean $C_{\max }$ of ETP in the group of rats administered $15 \mathrm{mg} / \mathrm{kg}$ was $57 \mu \mathrm{g} / \mathrm{mL}$. $\mathrm{C}_{\max }$ of ETP in the group of rats administered $15 \mathrm{mg} / \mathrm{kg}$ increased with increase in body weight (Fig. 2 (a)). On the other hand, the group of rats administered the adjusted dose achieved the target $\mathrm{C}_{\max }$ (Fig. 2 (a)). Moreover, when comparing the AUC at this time, the variation of ETP concentration was decreased in the adjustment group (Fig. 2 (b)).

\section{Discussion}

Although the standard conditioning regimen of $\mathrm{CY}+\mathrm{TBI}$ has been widely used before allo-SCT, the rate of mortality due to relapse is high and the results of treatment are not satisfactory [15-20]. Therefore, various intensified conditioning regimens, some of which used ETP combined with $\mathrm{CY}+\mathrm{TBI}$, have been developed. Many studies including studies in which ETP $(60 \mathrm{mg} / \mathrm{kg})$ was combined with CY and TBI $(\mathrm{ETP}+\mathrm{CY}+\mathrm{TBI})$ showed a low relapse rate but high rates of toxicity and transplant-related mortality [1-6]. We previously reported excellent outcomes for patients who received a medium-dose ETP $(30 \mathrm{mg} / \mathrm{kg})+$ $\mathrm{CY}+\mathrm{TBI}$ regimen at Hokkaido University Hospital in Japan $[10,11]$ and superior survival to that in patients who received CY + TBI retrospectively [12]. We also conducted a prospective phase II study. In that study, 1-year overall survival was $80.8 \%$ (95\% $\mathrm{Cl}=66.0$ - $88.7 \%)$. No

Table 2 Pharmacokinetic parameters of ETP after administration at a dose of $15 \mathrm{mg} / \mathrm{kg}$ once daily over $3 \mathrm{~h}$ for 2 days in patients $(n=20)$

\begin{tabular}{|c|c|c|c|c|c|c|}
\hline \multirow[t]{2}{*}{ Parameter } & \multicolumn{3}{|l|}{ Day 1} & \multicolumn{3}{|l|}{ Day 2} \\
\hline & Mean \pm S.D. & Median & Range & Mean \pm S.D. & Median & Range \\
\hline Cmax $(\mu \mathrm{g} / \mathrm{mL})$ & $74.9 \pm 17.0$ & 77.4 & $51.8-116.5$ & $77.5 \pm 12.9$ & 75.8 & $61.6-106.0$ \\
\hline Cmin $(\mu \mathrm{g} / \mathrm{mL})$ & $3.9 \pm 2.5$ & 3.7 & $0.2-9.1$ & $6.2 \pm 3.7$ & 5.4 & $1.6-16.1$ \\
\hline $\mathrm{Vd}(\mathrm{L} / \mathrm{kg})$ & $0.20 \pm 0.05$ & 0.19 & $0.12-0.29$ & $0.20 \pm 0.04$ & 0.20 & $0.14-0.27$ \\
\hline Kel $\left(h^{-1}\right)$ & $0.15 \pm 0.04$ & 0.14 & $0.10-0.29$ & $0.14 \pm 0.03$ & 0.14 & $0.07-0.20$ \\
\hline $\mathrm{CL}(\mathrm{mL} / \mathrm{h} / \mathrm{kg})$ & $30.9 \pm 14.5$ & 24.5 & $14.2-72.6$ & $29.0 \pm 8.5$ & 27.4 & $11.3-45.5$ \\
\hline AUC0-24 h or AUC24-44 h $(\mu \mathrm{g} \cdot \mathrm{h} / \mathrm{mL})$ & $634 \pm 154$ & 611 & $423-1021$ & $612 \pm 126$ & 586 & $424-852$ \\
\hline AUC0-92 h $(\mu \mathrm{g} \cdot \mathrm{h} / \mathrm{mL})$ & $1332 \pm 315$ & 1282 & $870-2015$ & & & \\
\hline
\end{tabular}


Table 3 Pharmacokinetic parameters of ETP after intravenous administration at a dose of $15 \mathrm{mg} / \mathrm{kg}$ in rats

\begin{tabular}{llll}
\hline & $\begin{array}{l}5 \text { weeks (control) } \\
120-150 \mathrm{~g}\end{array}$ & $\begin{array}{l}7 \text { weeks } \\
220-230 \mathrm{~g}\end{array}$ & $\begin{array}{l}10 \text { weeks } \\
320-355 \mathrm{~g}\end{array}$ \\
\hline AUC $(\mu \mathrm{g} \cdot \mathrm{h} / \mathrm{mL})$ & $12.8 \pm 0.33$ & $15.8 \pm 1.21^{*}$ & $20.4 \pm 3.01^{*}$ \\
$\mathrm{Cmax}(\mu \mathrm{g} / \mathrm{mL})$ & $49.0 \pm 9.73$ & $51.7 \pm 4.41$ & $71.8 \pm 7.57^{*}$ \\
$\mathrm{Vd}(\mathrm{L} / \mathrm{kg})$ & $0.32 \pm 0.07$ & $0.29 \pm 0.03$ & $0.21 \pm 0.02^{*}$ \\
$\mathrm{Kel}\left(\mathrm{h}^{-1}\right)$ & $1.72 \pm 0.26$ & $1.80 \pm 0.10$ & $1.84 \pm 0.38$ \\
$\mathrm{CL}(\mathrm{L} / \mathrm{h} / \mathrm{kg})$ & $0.54 \pm 0.12$ & $0.52 \pm 0.06$ & $0.39 \pm 0.10^{*}$ \\
\hline
\end{tabular}

Each value is the mean \pm S.D. of $3-4$ measurements

*Significantly different from control at $p<0.05$

patient died within 100 days post-SCT. The cumulative incidences of relapse and non-relapse mortality at 1-year post SCT were 10.0 and $14.0 \%$, respectively [13]. These data indicated that the addition of ETP was important for outcomes; however, there have been no study on PK of medium-dose ETP in adult patients with leukemia.

In this study, we focused on the PK of ETP with the aim of establishing the optimal dosage of ETP. Firstly, the plasma concentration and pharmacokinetic parameters of ETP in patients who received medium-dose ETP were determined. In most studies, 2-compartment models were used for PK analysis of ETP [21, 22]. However, we consider that $\alpha$-phase of etoposide is almost completed at the end of the administration because etoposide administered over $3 \mathrm{~h}$ and a semi-logarithmic plot of plasma concentration versus time appear as a single straight line. Therefore, we used 1- compartment model for analysis.

It was found that the plasma concentrations of ETP differed greatly among patients (Fig. 1, Table 2). The plasma concentrations of ETP should normally be about the same in all patients. Therefore, factors that account for the inter-individual variation in the plasma concentration of
ETP were investigated in this study. It has been reported that the steady-state concentration and AUC of continuous infusion of ETP were related to its toxicity [7, 23]. In this study, a significant relationship was found between $\mathrm{C}_{\max }$ and $\mathrm{AUC}_{0-92 \mathrm{~h}}(R=0.85, P<0.05)$. Therefore, we focused on factors that cause the inter-individual variation of $\mathrm{C}_{\max }$. Individual differences in $\mathrm{C}_{\max }$ are considered to be due to variation of $\mathrm{Vd}$ because $\mathrm{Vd}$ is calculated by the following equation: $V d=$ Dose $/ C_{\max }$. We found that $\mathrm{Vd}$ was correlated with Alb and body weight. Protein binding is important for PK of ETP. ETP is highly bound to Alb in plasma and the ratio of protein binding is $93 \%$ [24]. Stewart et al. reported that unbound ETP was significantly increased in cancer patients compared with that in normal volunteers [25]. These alterations in protein binding were significantly related to Alb [25]. A relationship between the ETP binding ratio and Alb was reported by Schwinghammer et al. $(R=0.57, P=0.02)$ [26].

About $35 \%$ of the administered dose of ETP is excreted into urine as the parent drug [27]. ETP clearance was significantly correlated with serum creatinine $(\mathrm{Scr})$ in previous studies $[28,29]$. In the present study, the renal function of 20 patients is normal range (Scr $0.3-1.0 \mathrm{mg} / \mathrm{dL}$ ). Therefore, we considered that $\mathrm{Vd}$ is important for patients with normal renal function. The study by Krogh-Madsen [22], baseline white blood cell count (bWBC) and sex influenced the PK of ETP. However, in this study, no correlation of bWBC and sex on PK of ETP. These results show that the variability of AUC could be reduced to adjust dosages by predicted $\mathrm{Vd}$ in patients with normal renal function.

We have investigated the study using rats whether to reduce the variation of ETP concentration by dose adjustment by prediction of $\mathrm{Vd}$. Our in vivo study in rats suggested that increase of ETP plasma concentration was mainly associated with increase of body weight

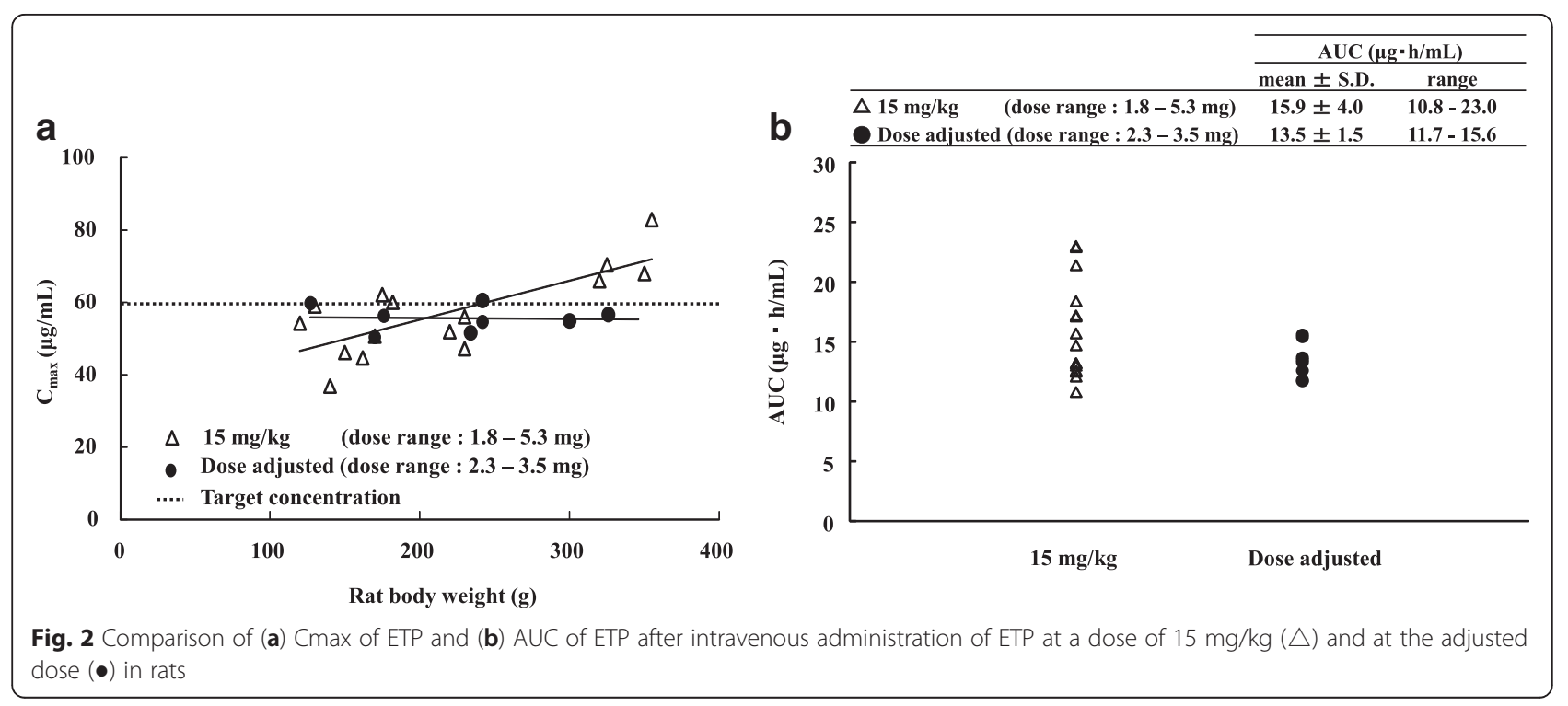


(Table 3). In addition, body weight of rats was strongly correlated with $\mathrm{Vd}(R=0.82, P<0.05)$. Therefore, we predicted Vd by only body weight of rats and calculated the dose of ETP so as to achieve a target ETP plasma concentration $(60 \mu \mathrm{g} / \mathrm{mL})$. As a result, the group of rats with dose adjustment achieved the target ETP plasma concentration and the variation of plasma ETP concentration was decreased. These results indicate that body weight is very important for pharmacokinetic parameters of ETP, especially Vd.

In the investigation using rats, it was shown that body weight is very important for $\mathrm{Vd}$ and that $\mathrm{Vd}$ can be predicted by body weight. In general, the body surface area (BSA) is used in dose adjustment of chemotherapy. However, there was high inter-individual variation in plasma concentration of ETP, even if dose of ETP was adjusted based on BSA [21]. In addition, body weightbased dose has been widely used in conditioning regimens $[8,9,19]$. Therefore, we use body weight to determine the dosage.

In clinical investigations, we focused on only Vd because there was a strong correlation between $\mathrm{C}_{\max }$ and AUC. However, $K_{\mathrm{el}}$ is critical for estimating ETP plasma concentration as well as Vd. In addition, the target ETP plasma concentration in medium dose ETP therapy has not been clarified. According to our preliminary analysis, ETP plasma concentration $\geq 75.6 \mu \mathrm{g} / \mathrm{mL}$ was associated with a high mortality rate. However, correlations between results of pharmacokinetic analysis and clinical outcomes were not sufficient in this study due to the small sample size. Further studies are needed to establish the optimal dose of ETP and confirm correlations between pharmacokinetic parameters of ETP and clinical outcomes in different patient populations.

\section{Conclusions}

The results suggested that inter-individual variation of plasma concentration of ETP could be reduced by predicting Vd. Prediction of Vd is effective for reducing individual variation of ETP concentration and might enable a good therapeutic effect to be achieved.

\footnotetext{
Abbreviations

Alb, albumin; ALL, acute lymphoblastic leukemia; allo-SCT, allogeneic stem cell transplantation; ALT, alanine aminotransferase; AML, acute myelogenous leukemia; ANKL, aggressive NK cell leukemia; AST, asparatate aminotransferase; AUC, area under the plasma concentration-time curve; BUN, blood urea nitrogen; $\mathrm{Cl}$, confidence intervals; $\mathrm{CL}$, Clearance; $\mathrm{C}_{\text {max }}$, peak concentration; $\mathrm{C}_{\text {min }}$, trough concentration; $\mathrm{CR}$, complete remission; CSP, cyclosporine; CY, cyclophosphamide; DMSO, dimethyl sulfoxide; DPH, diphenyl hydantoin; ETP, etoposide; GVHD, graft-versus-host disease; HPLC, high-performance liquid chromatography; i.v., intravenously; $\mathrm{K}_{\mathrm{el}}$, elimination rate constant; MMRD, mismatched related donor; MMUD, mismatched unrelated donor; MRD, HLA-matched related donor; MTX, methotrexate; MUD, HLA-matched unrelated donor; PK, pharmacokinetics; RMSE, root mean squared error; Scr, serum creatinine; TAC, Tacrolimus; TBI, total body irradiation; T-bil, total bilirubin; T-pro, total protein; Vd, distribution volume
}

\section{Acknowledgements}

We thank the patients who participated in this study, the physicians and staff members of Hokkaido University Hospital who contributed valuable data. This study was supported in part by JSPS KAKENHI Grant Number 25460203 and Japan Research Foundation for Clinical Pharmacology.

\section{Authors' contributions}

YT performed experiments, analyzed data, and draft the manuscript. AS and KK designed and coordinated the study. AS, JS TE, TK and TT helped to collect samples. KI, MS and YT helped to interpretation of data. All authors read and approved the final manuscript.

\section{Competing interests}

The authors declare that they have no competing interests.

\section{Author details}

${ }^{1}$ Laboratory of Pharmacokinetics, Faculty of Pharmaceutical Sciences, Hokkaido University, Kita-12 Nishi-6, Kita-ku, Sapporo, Hokkaido 060-0812, Japan. ${ }^{2}$ Department of Hematology, Hokkaido University Graduate School of Medicine, Sapporo, Japan. ${ }^{3}$ Department of Pharmacy, Hokkaido University Hospital, Sapporo, Japan. ${ }^{4}$ Education Research Center for Clinical Pharmacy, Faculty of Pharmaceutical Sciences, Hokkaido University, Sapporo, Japan.

Received: 8 March 2016 Accepted: 5 July 2016

Published online: 08 August 2016

References

1. Bostrom B, Weisdorf DJ, Kim T, Kersey JH, Ramsay NK. Bone marrow transplantation for advanced acute leukemia: a pilot study of high-energy total body irradiation, cyclophosphamide and continuous infusion etoposide. Bone Marrow Transplant. 1990;5:83-9.

2. Giralt SA, LeMaistre CF, Vriesendorp HM, Andersson BS, Dimopoulos M, Gajewski J, et al. Etoposide, cyclophosphamide, total-body irradiation, and allogeneic bone marrow transplantation for hematologic malignancies. J Clin Oncol. 1994;12:1923-30.

3. Petersen FB, Buckner CD, Appelbaum FR, Sanders JE, Bensinger WI, Storb R, et al. Etoposide, cyclophosphamide and fractionated total body irradiation as a preparative regimen for marrow transplantation in patients with advanced hematological malignancies: a phase I study. Bone Marrow Transplant. 1992;10:83-8

4. Yau JC, LeMaistre CF, Andersson BS, Huan SD, Wallerstein RO, Woo SY, et al. Allogeneic bone marrow transplantation for hematological malignancies following etoposide, cyclophosphamide, and fractionated total body irradiation. Am J Hematol. 1992;41:40-4.

5. Brown RA, Wolff SN, Fay JW, Pineiro L, Collins Jr RH, Lynch JP, et al. High-dose etoposide, cyclophosphamide, and total body irradiation with allogeneic bone marrow transplantation for patients with acute myeloid leukemia in untreated first relapse: a study by the North American Marrow Transplant Group. Blood. 1995;85:1391-5.

6. Brown RA, Wolff SN, Fay JW, Pineiro L, Collins Jr RH, Lynch JP, et al. High-dose etoposide, cyclophosphamide and total body irradiation with allogeneic bone marrow transplantation for resistant acute myeloid leukemia: a study by the North American Marrow Transplant Group. Leuk Lymphoma. 1996;22:271-7.

7. Miller AA, Stewart CF, Tolley EA. Clinical pharmacodynamics of continuousinfusion etoposide. Cancer Chemother Pharmacol. 1990;25:361-6.

8. Chrzanowska M, Sobiak J, Grund G, Wachowiak J. Pharmacokinetics of highdose etoposide administered in combination with fractionated total-body irradiation as conditioning for allogeneic hematopoietic stem cell transplantation in children with acute lymphoblastic leukemia. Pediatr Transplant. 2011;15:96-102

9. Mross K, Reifke J, Bewermeier P, Kruger W, Hossfeld DK, Zander A. The pharmacokinetics and toxicity of two application schedules with high-dose VP-16 in patients receiving an allogeneic bone marrow transplantation. Ann Oncol. 1996;7:83-8.

10. Toubai T, Tanaka J, Mori A, Hashino S, Kobayashi S, Ota S, et al. Efficacy of etoposide, cyclophosphamide, and total body irradiation in allogeneic bone marrow transplantation for adult patients with hematological malignancies. Clin Transplant. 2004;18:552-7.

11. Shigematsu A, Kondo T, Yamamoto S, Sugita J, Onozawa M, Kahata K, et al. Excellent outcome of allogeneic hematopoietic stem cell transplantation 
using a conditioning regimen with medium-dose VP-16, cyclophosphamide and total-body irradiation for adult patients with acute lymphoblastic leukemia. Biol Blood Marrow Transplant. 2008;14:568-75.

12. Shigematsu A, Tanaka J, Suzuki R, Atsuta Y, Kawase T, Ito YM, et al. Outcome of medium-dose VP-16/CY/TBI superior to CY/TBI as a conditioning regimen for allogeneic stem cell transplantation in adult patients with acute lymphoblastic leukemia. Int J Hematol. 2011;94:463-71.

13. Shigematsu A, Ozawa Y, Onizuka M, Fujisawa S, Suzuki R, Atsuta Y, et al. A safety and efficacy study of medium-dose etoposide, cyclophosphamide and total body irradiation conditioning before allogeneic stem cell transplantation for acute lymphoblastic leukemia. Transplant Direct. 2015;1:1-7.

14. Kato Y, Mawatari H, Nishimura S, Sakura N, Ueda K. Determination of etoposide serum concentrations in small pediatric samples by an improved method of reversed-phase high-performance liquid chromatography. Acta Med Okayama. 2003;57:21-4.

15. Sebban C, Lepage E, Vernant JP, Gluckman E, Attal M, Reiffers J, et al. Allogeneic bone marrow transplantation in adult acute lymphoblastic leukemia in first complete remission: a comparative study. French Group of Therapy of Adult Acute Lymphoblastic Leukemia. J Clin Oncol. 1994:12:2580-7.

16. Horowitz MM, Messerer D, Hoelzer D, Gale RP, Neiss A, Atkinson K, et al. Chemotherapy compared with bone marrow transplantation for adults with acute lymphoblastic leukemia in first remission. Ann Intern Med. 1991;115:13-8

17. Hahn T, Wall D, Camitta B, Davies S, Dillon H, Gaynon P, et al. The role of cytotoxic therapy with hematopoietic stem cell transplantation in the therapy of acute lymphoblastic leukemia in adults: an evidence-based review. Biol Blood Marrow Transplant. 2006;12:1-30.

18. Thomas X, Boiron JM, Huquet F, Dombret H, Bradstock K, Vey N, et al. Outcome of treatment in adults with acute lymphoblastic leukemia: analysis of the LALA-94 trial. J Clin Oncol. 2004;22:4075-86.

19. Hunault M, Harousseau JL, Delain M, Truchan-Graczyk M, Cahn JY, Witz F, et al. Better outcome of adult acute lymphoblastic leukemia after early genoidentical allogeneic bone marrow transplantation (BMT) than after late high-dose therapy and autologous BMT: a GOELAMS trial. Blood. 2004;104:3028-37.

20. Attal M, Blaise D, Marit G, Payen C, Michallet M, Vernant JP, BGMT Group, et al. Consolidation treatment of adult acute lymphoblastic leukemia: a prospective, randomized trial comparing allogeneic versus autologous bone marrow transplantation and testing the impact of recombinant interleukin-2 after autologous bone marrow transplantation. Blood. 1995;86:1619-28.

21. You B, Salles G, Bachy E, Casasnovas O, Tilly H, Ribrag V, Sebban C, Hénin E, Guitton J, Tod M, Freyer G. Etoposide pharmacokinetics impact the outcomes of lymphoma patients treated with BEAM regimen and ASCT: a multicenter study of the LYmphoma Study Association (LYSA). Cancer Chemother Pharmacol. 2015;76:939-48.

22. Krogh-Madsen M, Bender B, Jensen MK, Nielsen OJ, Friberg LE, Honoré PH. Population pharmacokinetics of cytarabine, etoposide, and daunorubicin in the treatment for acute myeloid leukemia. Cancer Chemother Pharmacol. 2012;69:1155-63.

23. Bennett CL, Sinkule JA, Schilsky RL, Senekjian E, Choi KE. Phasel clinical and pharmacological study of 72-h continuous infusion of etoposide in patients with advanced cancer. Cancer Res. 1987;47:1952-6.

24. Liu B, Earl HM, Poole CJ, Dunn J, Kerr DJ. Etoposide protein binding in cancer patients. Cancer Chemother Pharmacol. 1995;36:506-12.

25. Stewart CF, Pieper JA, Arbuck SG, Evans WE. Altered protein binding of etoposide in patients with cancer. Clin Pharmacol Ther. 1989;45:49-55.

26. Schwinghammer TL, Fleming RA, Rosenfeld CS, Przepiorka D, Shadduck RK, Bloom EJ, et al. Disposition of total and unbound etoposide following high-dose therapy. Cancer Chemother Pharmacol. 1993;32:273-8.

27. Hande KR, Wedlund PJ, Noone RM, Wilkinson GR, Greco FA, Wolff SN Pharmacokinetics of high-dose etoposide (VP-16-213) administered to cancer patients. Cancer Res. 1984;44:379-82.

28. You B, Tranchand B, Girard P, Falandry C, Ribba B, Chabaud S, Souquet PJ, Court-Fortune I, Trillet-Lenoir V, Fournel C, Tod M, Freyer G. Etoposide pharmacokinetics and survival in patients with small cell lung cancer: a multicentre study. Lung Cancer. 2008:62:261-72.

29. Nguyen L, Chatelut E, Chevreau C, Tranchand B, Lochon I, Bachaud JM, Pujol A, Houin G, Bugat R, Canal P. Population pharmacokinetics of total and unbound etoposide. Cancer Chemother Pharmacol. 1998;41:125-32.

\section{Submit your next manuscript to BioMed Central and we will help you at every step:}

- We accept pre-submission inquiries

- Our selector tool helps you to find the most relevant journal

- We provide round the clock customer support

- Convenient online submission

- Thorough peer review

- Inclusion in PubMed and all major indexing services

- Maximum visibility for your research

Submit your manuscript at www.biomedcentral.com/submit
Biomed Central 